\title{
BƯớC ĐẦU NGHIÊN CÚU NƯớC DÂNG DO HIỆU ỨNG BƠM EKMAN TẠI VEN BIỂN MIỀN TRUNG
}

\author{
Nguyễn Bá Thủy ${ }^{1}$, Nguyễn Kim Cương²
}

Tóm tắt: Nghiên cứu này áp dụng mô hình ROMS 3D vào mô phỏng hiện tượng mưc nước biển dâng cao bất thuoòng trong đợt triều cuờng tháng 12 năm 2016 tại Tuy Hòa-Phú Yên nhằm xác định nuớc dâng gây bởi hiệu ưng bơm Ekman tại khu vục. Các truờng khí tương được thu thập tù co sở dũ liệu tái phân tích của CFSR. Kết quả cho thấy, diễn biến nước dâng do hiệu ứng bơm Ekman khá tuoong đồng với nước dâng quan trắc nhưng thiên thấp. Truờng gió Đông Bắc mạnh, kéo dài gây hệ thống dòng chảy có vận tốc lớn dọc ven bờ miền Trung tạo hiệu ứng bơm Ekman đẩy mưc nước dâng cao tại Tuy Hòa-Phú Yên.

Từ khóa: Nước dâng dị thường, bơm Ekman, Tuy Hòa.

Ban Biên tập nhận bài: 12/03/2019 Ngày phản biện xong: 26/05/2019 Ngày đăng bài: 25/6/2019

\section{Mở đầu}

Nghiên cứu về nước dâng do bão, áp thấp nhiệt đới đã được tiến hành từ rất lâu do bởi thiệt hại gây bởi nước dâng trong bão rất lớn. Chính vì vậy, nhiều công nghệ dự báo nước dâng do bão đã được xây dựng để phục vụ dự báo, cảnh báo. Qua đó, nhiều mô hình thương mại (Delft3D, Mike2D, SMS...) cũng như mã nguồn mở (ROMS, POM....) được ứng dụng để phục vụ dự báo, cảnh báo. Ngoài hiện tượng nước dâng do bão và áp thấp nhiệt đới, tại nhiều khu vực trên thế giới khi gió có vận tốc lớn, thổi theo hướng ổn định và kéo dài cũng gây nước dâng đáng kể tại vùng ven bờ. Chính vì vậy, nước dâng do gió mùa gần đây đã được tập chung nghiên cứu và xây dựng công nghệ dự báo, nhất là tại những khu vực có địa hình trên bờ trũng và biên độ thủy triều lớn, chỉ cần xuất hiện nước dâng cỡ vài chục centimet vào kỳ triều cường có thể gây ngập trên diện rộng. Nước dâng gây bởi gió được tạo bởi theo 3 cơ chế: Tác động trực tiếp từ ứng suất gió trên bề mặt biển; tác động ${ }^{1}$ Trung tâm Dụ báo khí tương thủy văn quốc gia ${ }^{2}$ Truòng Đại hoc Khoa học Tụ nhiên - Đại học Quốc gia Hà Nội

Email: thuybanguyen@gmail.com gián tiếp qua ứng suất sóng; và hiệu ứng bơm Ekman đẩy mực nước ven bờ dâng cao do dòng chảy dọc bờ. Tuy nhiên, từ số liệu quan trắc thực tế, việc xác định mức độ đóng góp của nước dâng do hiệu ứng nào gây nên là rất khó.Chúng ta chỉ có thể xác định nước dâng gây bởi các hiệu ứng riêng rẽ thông qua kết quả mô phỏng bằng mô hình số trị. Nước dâng do tác động trực tiếp từ ứng suất gió thường lớn trong trường hợp gió mạnh trong bão, áp thấp nhiệt đới, cơ chế gây nước dâng này đã được nghiên cứu nhiều. Hiện tượng mực nước dâng cao do hiệu ứng bơm Ekman xuất hiện tại những khu vực bờ biển có vận tốc dòng chảy dọc bờ lớngây bởi gió mạnh thổi theo hướng ổn định trong thời gian dài. Bơm Ekman có thể là hiệuứng nước dâng hoặc rút tùy theo hướng hội tụ hay phân kỳ của hoàn lưu dòng chảy. Hiện tượng nước dâng do hiệu ứng bơm Ekman cũng đã được nghiên cứu trong bão, áp thấp nhiệt đới và gió mùa như trong các nghiên cứu của Kim và nnk (2014) [6], Bertin và nnk (2015) [3]. Ngay trong khu vực Biển Đông cũng đã có một số nghiên cứu đề cập tới nước dâng do hiệu ứng bơm Ekman tại ven bờ miền Trung $[4,7]$. Nghiên cứu của Centurion và nnk (2009) dựa theo số liệu quan trắc dòng 
chảy tại tầng $20 \mathrm{~m}$ và mô hình cho thấy dòng Ekman trong mùa đông tại ven bờ miền Trung tương gây nên dị thường mực nước rất đáng kể, khoảng 20-30cm [4]. Nhóm tác giả Shaw và nnk (1998) khi phân tích số liệu mực nước từ vệ tinh Topex/Poseidon trong thời gian từ 1992-1995 đưa ra kết luận rằng dị thường mực nước là dương khoảng 0,18-0,2m đối với ven bờ biển Việt Nam từ Phú Yên trở xuống. Nhóm tác giả cũng đưa ra lý giải nguyên nhân do hệ thống dòng chảy mạnh dọc bờ trong mùa Đông tại khu vực [7].

Số liệu quan trắc nhiều mực nước nhiều năm tại trạm thủy văn Phú Lâm (cách cửa biển Tuy Hòa $2 \mathrm{~km}$ ) và số liệu tại trạm nghiệm triều đặt tại cửa biển Tuy Hòa-Phú Yên tháng 12 năm 2016 đã cho thấy có hiện tượng nước dâng cao bất thường trên nền thủy triều trong các đợt triều cường tại khu vực [1]. Theo nghiên cứu của Nguyễn Bá Thủy và Trần Quang Tiến năm 2017, các đợt triều cường cao tại Tuy Hòa-Phú Yên thường gắn với hình thế thời tiết kết hợp giữa gió mùa Đông Bắc mạnh ở ven biển Trung Bộ và vùng thấp ngoài khơi giữa và nam Biển Đông có hướng di chuyển vào ven biển Việt Nam [2].

Để xem xét nguyên nhân gây mực nước dị thường tại khu vực ngoài tác động của ứng suất gió và ứng suất sóng thì vài trò của hiệu ứng Ekman do dòng chảy ven bờ tác động tới nước dâng ra sao, mô hình ROMS 3D được áp dụng để mô phỏng nước dâng trong đợt triều cường tháng 12 năm 2016 tại Tuy Hòa-Phú Yên. Kết quả của nghiên cứu sẽ góp phần làm sáng tỏ nguyên nhân gây nước dâng dị thường tại khu vực.

\section{Phương pháp nghiên cứu}

Nghiên cứu này sử dụng mô hình ROMS 3D để mô phỏng hiện tượng mực nước dâng dị thường trong đợt triều cường tháng 12 năm 2016 nhằm mục đích xác định nước dâng do hiệu ứng Ekman tại khu vực. ROMS là mô hình đại dương quy mô khu vực được phát triển bởi đại học California và đại học Rutgers (Hoa Kỳ) [11]. Là mô hình mã nguồn mở nên ROMS mang tính cộng đồng cao, được nhiều nhà nghiên cứu sử dụng với qui mô không gian và thời gian khác nhau: Từ dải ven bờ tới các đại dương thế giới; mô phỏng cho vài ngày, vài tháng và tới hàng chục năm. Mô hình ROMS được xây dựng trên cơ sở các nghiên cứu số trị bậc cao mới nhất cùng với kỹ thuật tiên tiến cho phép triển khai một cách có hiệu quả các tính toán có độ phân giải cao. Mô hình giải các phương trình thuỷ tĩnh cho thủy vực có bề mặt tự do với địa hình đáy phức tạp trên hệ lưới cong trực giao theo phương ngang và thích ứng địa hình theo phương thẳng đứng. Với bài toán mô phỏng nước dâng do hiệu ứng bơm Ekman ven bờ, mô hình ROMS phiên bản $3 \mathrm{D}$ được lựa chọn. Chi tiết về mô hình ROMS có thể được tham khảo tại [11]. Miền tính cho cho mô hình ROMS $3 \mathrm{D}$ từ $1-23^{\circ} \mathrm{N}$ và $99-121^{\circ} \mathrm{E}$ (Hình 1$)$, với độ phân giải không gian $5 \mathrm{~km}$ và 30 lớp (theo độ sâu). Với miền tính như trên, tổng số điểm nút lưới là 421 x 448 x 30 điểm. Tại các biên lỏng, các kết quả từ hệ thống mô hình HYCOM với độ phân giải $1 / 12^{\circ}$ được thu thập và đưa vào mô hình như điều kiện biên và điều kiện ban đầu [8]. Các hằng số điều hòa thủy triều nhận từ hệ thống OTPS của trường ĐH Oregon, Mỹ [9]. Các trường khí tượng như gió, khí áp, bức xạ .... được thu thập từ cơ sở dữ liệu tái phân tích CFSR (Climate Forecast System Reanalysis) [10]. 


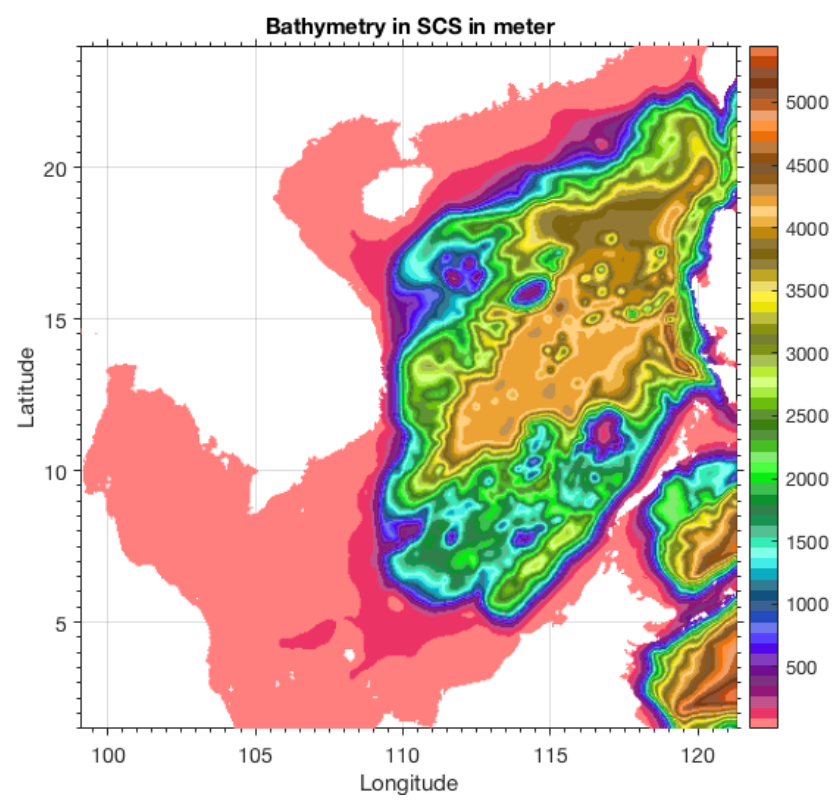

Hình 1. Phân bố độ sâu của miền tính toán của mô hình ROMS 3D

\section{Kết quả mô phỏng}

Nghiên cứu sử dụng số liệu quan trắc mực nước tại trạm nghiệm triều đặt tại cửa biển Tuy Hòa tháng 12 năm 2016 để so sánh với kết quả mô phỏng [1]. Các kết quả mô phỏng để phân tích và kiểm chứng bao gồm mực nước tổng cộng, thủy triều và dòng chảy theo các tầng trong tháng 12 năm 2016. Trên hình 2 là phân bố trường gió và khí áp của dữ liệu CFSR trong đợt nước triều cường này.Về cơ bản nguồn số liệu khí tượng này khá tương đồng với số liệu tái phân tích của Cơ quan Khí tượng hạn vừa Châu Âu thể hiện hình thế thời tiết trong thời gian này bị chi phối bởi gió mùa Đông Bắc mạnh lấn sâu xuống Nam Trung Bộ, bên cạnh đó ngoài khơi Nam Biển Đông hình thành khối áp thấp di chuyển chậm vào ven bờ Nam Trung Bộ và Nam Bộ, sau đó tan do ảnh hưởng của không khí lạnh.

So sánh kết quả tính toán và quan trắc mực nước tổng cộng (bao gồm cả thủy triều và dao động dâng/rút do gió) trên hình 3 cho thấy có sự tương đồng về pha và độ lớn của mực nước mô phỏng và quan trắc. Hai chuỗi số liệu có hệ số tương quan tương đối cao $(80 \%)$. Trong nửa đầu của tháng 12 năm 2016, mô hình mô phỏng tương đối tốt dao động mực nước. Tuy nhiên, từ tuần thứ 3 của tháng 12 , mô hình đã mô phỏng tương đối tốt các đỉnh triều nhưng mô phỏng chưa thực sự tốt tại các thời điểm mực nước thấp.
Đây cũng chính là thời gian xảy ra hiện tượng nước dâng dị thường tại khu vực này. Để đánh giá định lượng nước dâng, phương án chỉ tính thủy triều được thực hiện và nước dâng được xác định sau khi loại bỏ thủy triều từ mực nước tổng hợp. So sánh nước dâng tính từ mô hình với quan trắc tại Tuy Hòa được thể hiện trên hình 4 . Kết quả cho thấy, mặc dù đỉnh nước dâng còn thiên thấp nhưng mô hình ROMS 3D cũng đã phản ánh được $x u$ thế nước dâng, với đỉnh vào đêm ngày $14 / 12$ là $0.18 \mathrm{~m}$ (thực tế $0,59 \mathrm{~m}$ ) và đêm ngày $16 / 12$ là $0,31 \mathrm{~m}$ (thực tế $0,61 \mathrm{~m}$ ). Với mô hình ROMS 3D, ảnh hưởng của sóng không được xét tới nên nước dâng tính toán chủ yếu do tác động trực tiếp của ứng suất gió lên mặt biển và gián tiếp qua hiệu ứng bơm Ekmam. Trên hình 5 và 6 là trường mực nước và dòng chảy tại các tầng $0 \mathrm{~m}, 50 \mathrm{~m}$ và $100 \mathrm{~m}$ ở thời điểm trước $\mathrm{khi}$ xuất hiện nước dâng cao nhất vào đêm ngày $14 / 12$ và $16 / 12$. Có thể thấy rằng, gió mùa Đông Bắc đã tạo nên hệ thống dòng chảy mạnh dọc ven bờ miền Trung tại cả 3 tầng với vận tốc tới $1 \mathrm{~m} / \mathrm{s}$, khi tới Tuy Hòa, điểm cực Đông nhất của Việt Nam, dòng chảy hướng ra ngoài biển, và ngay sau đó chuyển hướng vào bờ đẩy mực nước tại đây dâng cao. Cơ chế này cũng có thể lý giải tại sao thông tin về triều cường cao xuất hiện chủ yếu ở khu vực quanh Tuy Hòa-Phú Yên và thỉnh thoảng xuất hiện tại một số khu vực ở phía Nam 


\section{BÀI BÁO KHOA HỌC}

Tuy Hòa.Kết quả mô phỏng trường dòng chảy bằng mô hình ROMS $3 \mathrm{D}$ cũng cho thấy hiện tượng nàykhông ít sảy ratại thời điểm thủy triều

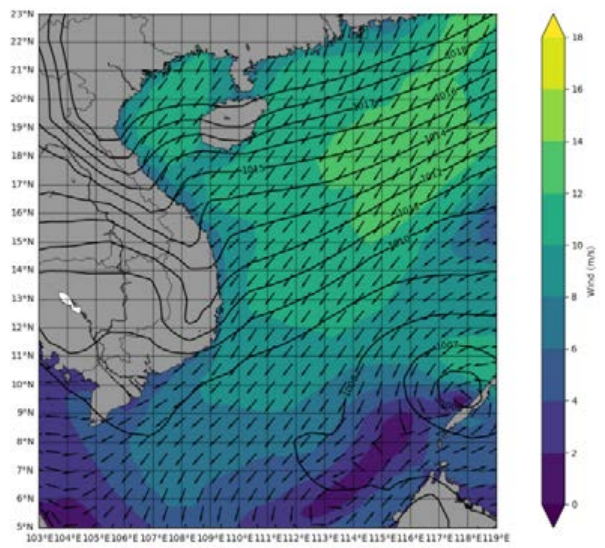

(a) 18 giờ ngày $20 / 12 / 2014$

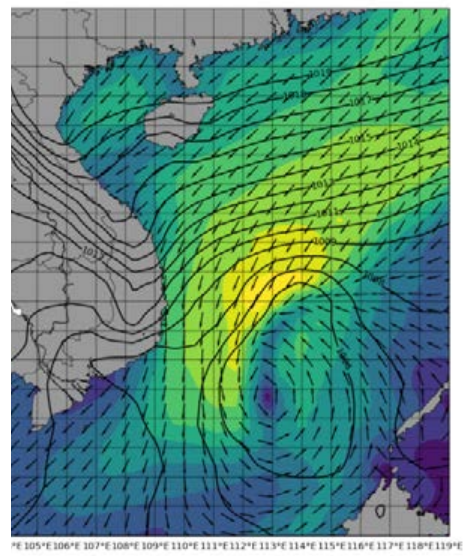

c) 18 giờ ngày $22 / 12 / 2014$

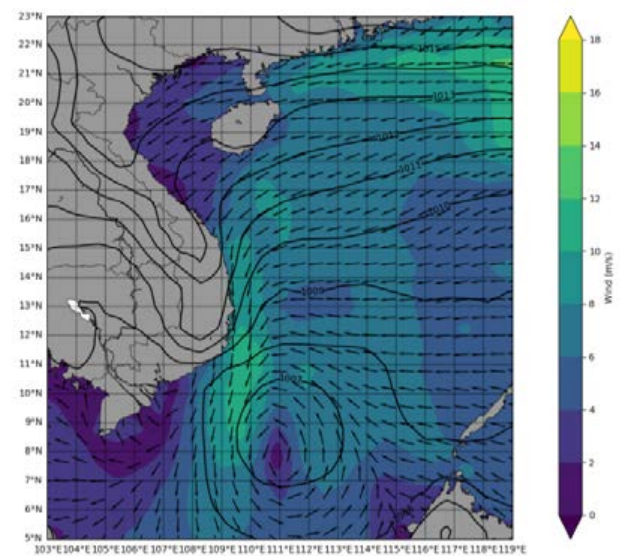

(e) 18 giờ ngày 24/12/2014 thấp, như minh họa trên hình 7vào ngày 8 và 9 tháng 12

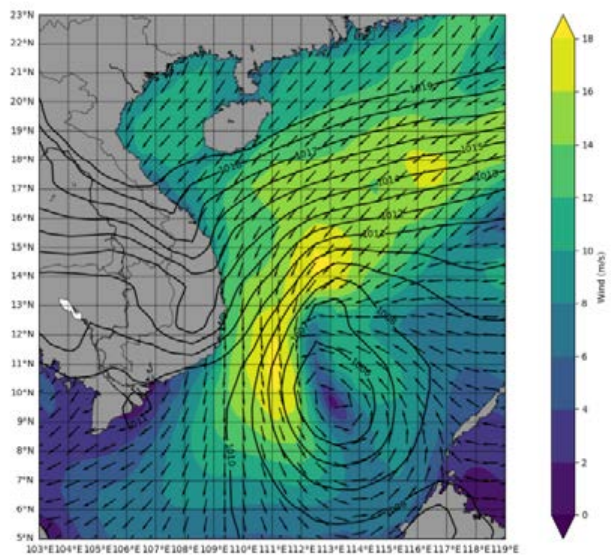

(b) 18 giờ ngày 21/12/2014

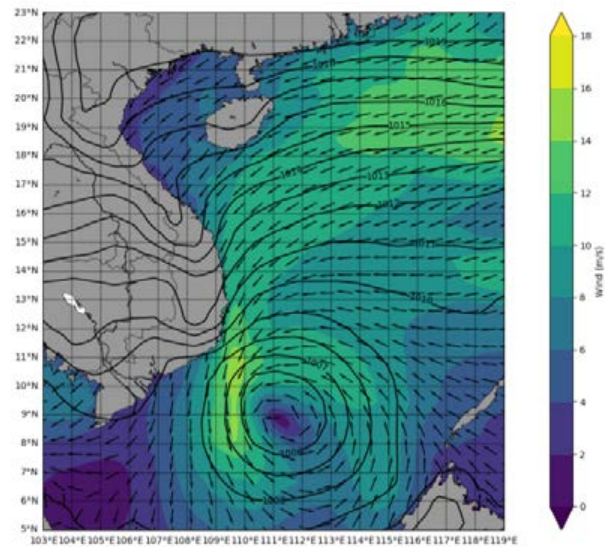

(d) 18 giờ ngày 23/12/2014

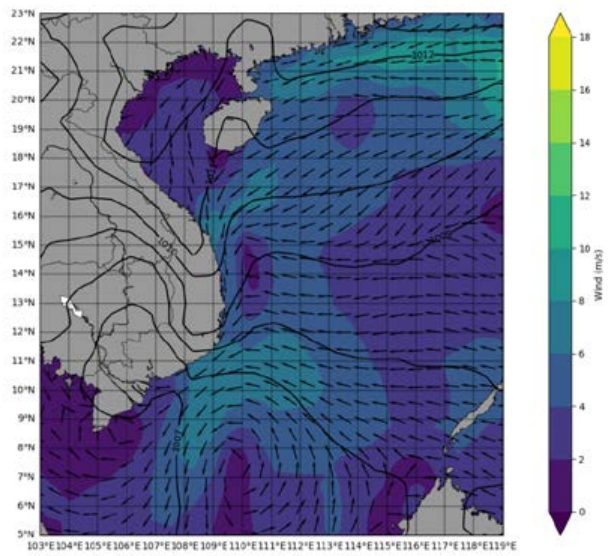

(f) 18 giờ ngày 25/12/2014

Hình 2. Truò̀ng gió và khí áp tù cở sở dũ liệu CFSR trong đọt triều cuòng tháng 12 năm 2016 


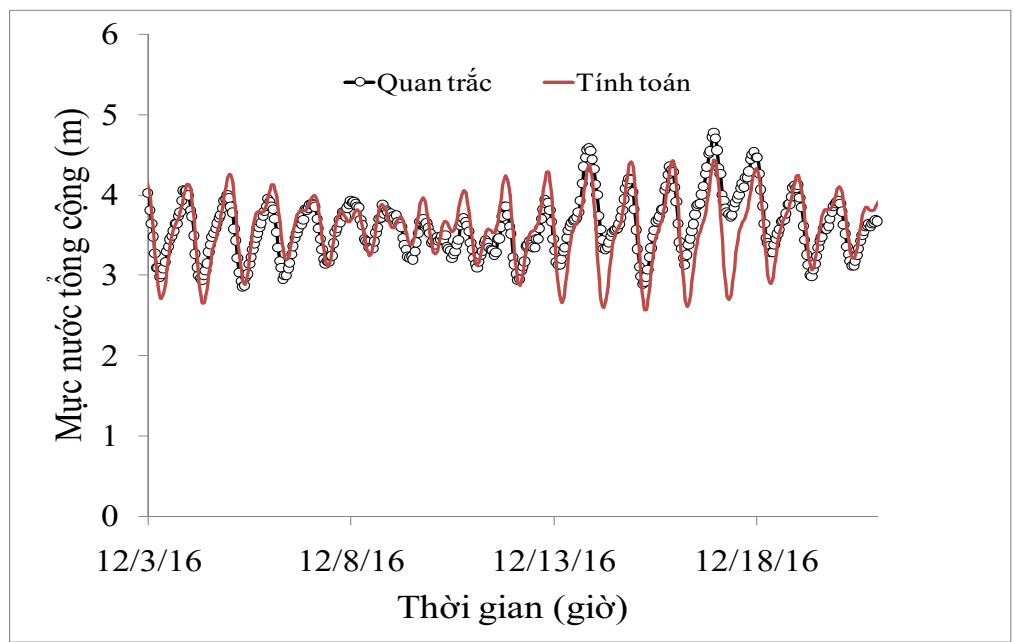

Hình 3. So sánh biến thiên mưc nước tính toán và quan trắc trong đợt triều cường tháng 12 năm 2016 tại trạm quan trắc bổ sung Tuy Hòa

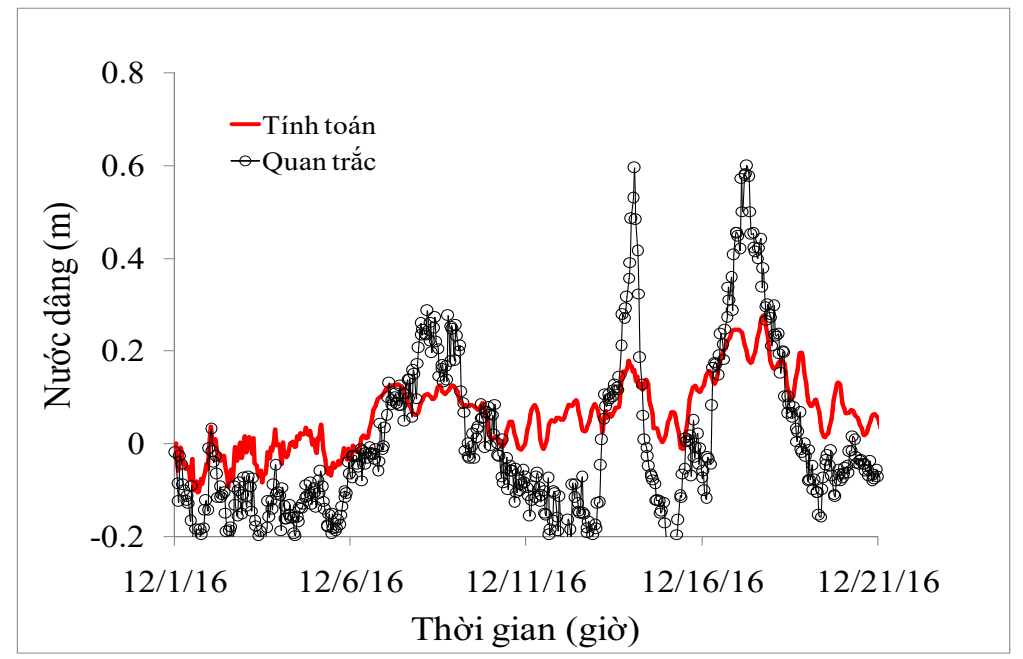

Hình 4. So sánh biến thiên nước dâng tính toán và quan trắc trong đợt triều cuờng tháng 12 năm 2016 tại trạm quan trắc bổ sung Tuy Hòa

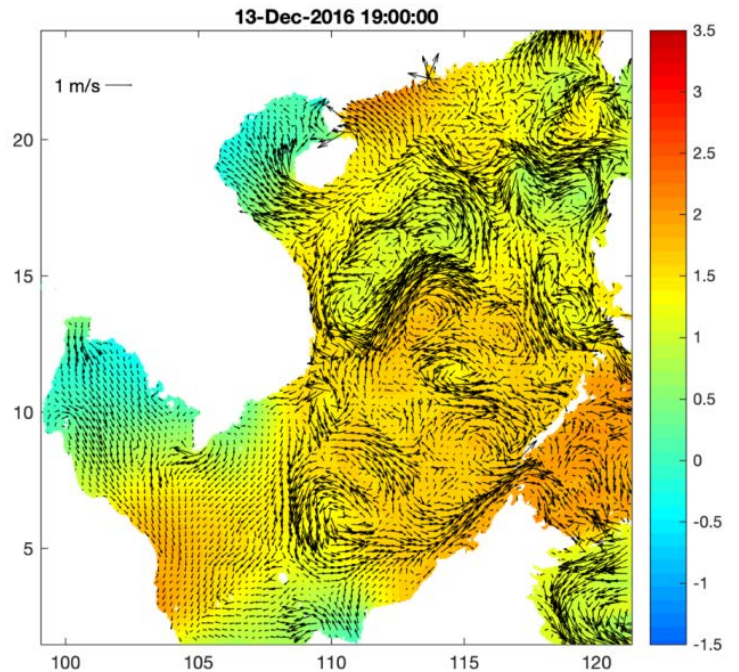

(a)

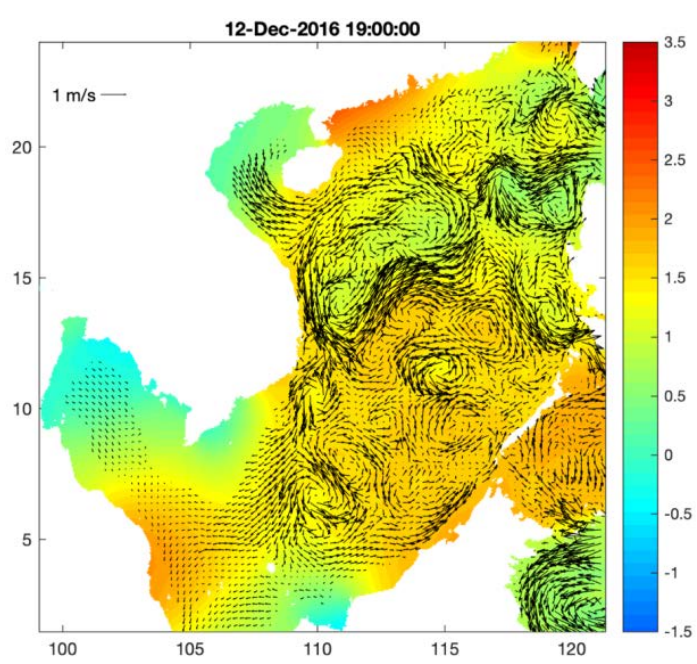

(b) 


\section{BÀI BÁO KHOA HỌC}

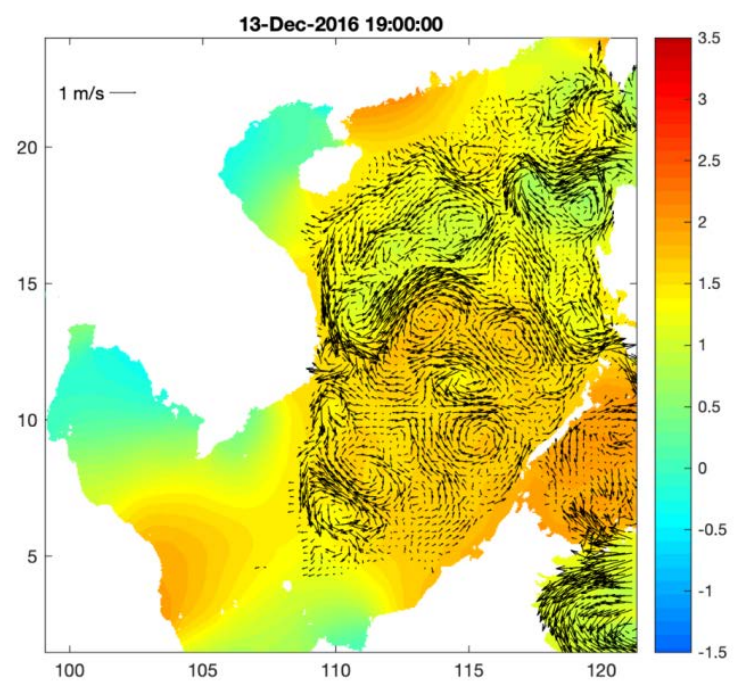

(c)

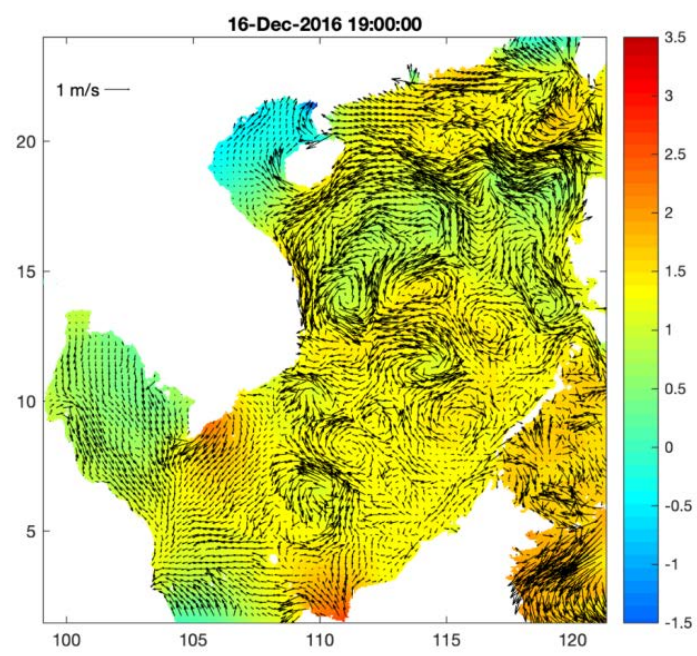

(a)

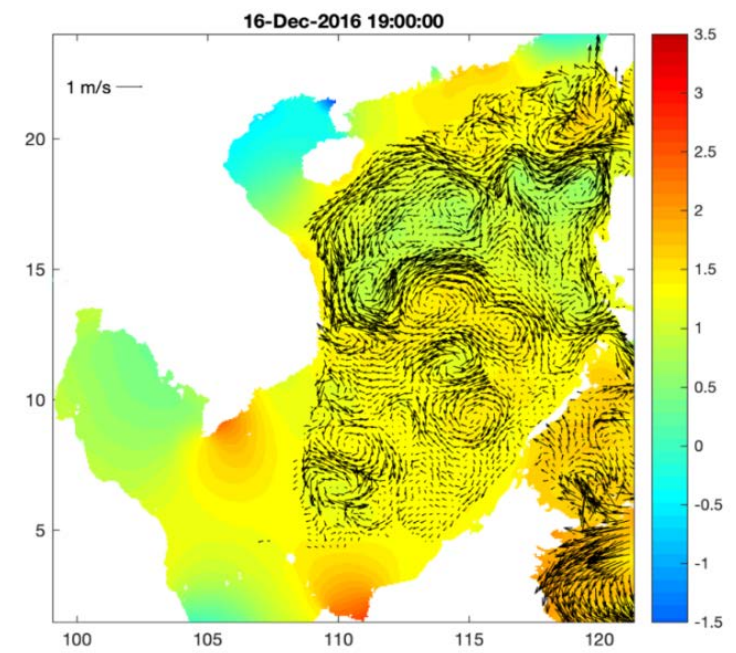

(c)
Hình 5. Truờng mưc nước và dòng chảy tại tầng $0 \mathrm{~m}$ (a), $50 \mathrm{~m}$ (b) và $100 \mathrm{~m}$ (c) tại thời điểm truớc khi xuất hiện nước dâng lớn nhất ngày 14/12/2016

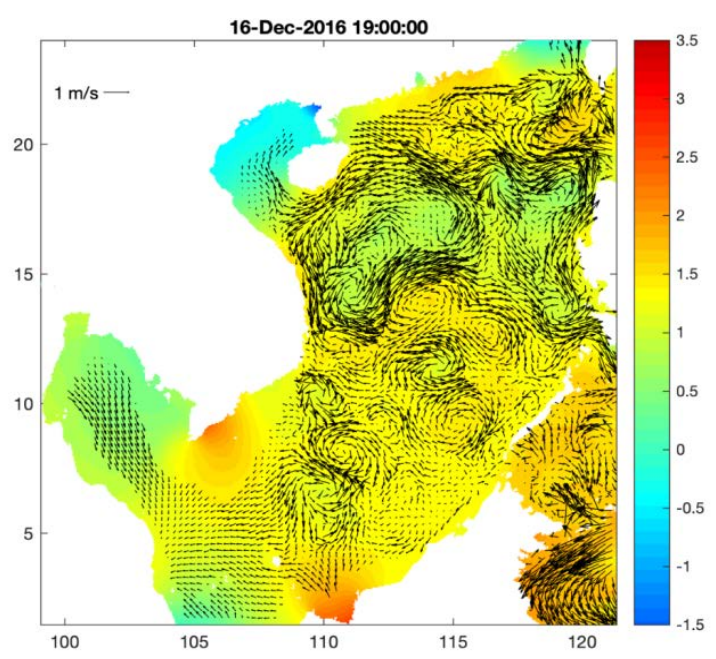

(b)

Hình 6. Trường mưc nước và dòng chảy tại tầng $0 m$ (a), $50 m$ (b) và $100 m$ (c) tại thời điểm truớc khi xuất hiện nước dâng lớn nhất ngày

$$
\text { 16/12/2016 }
$$




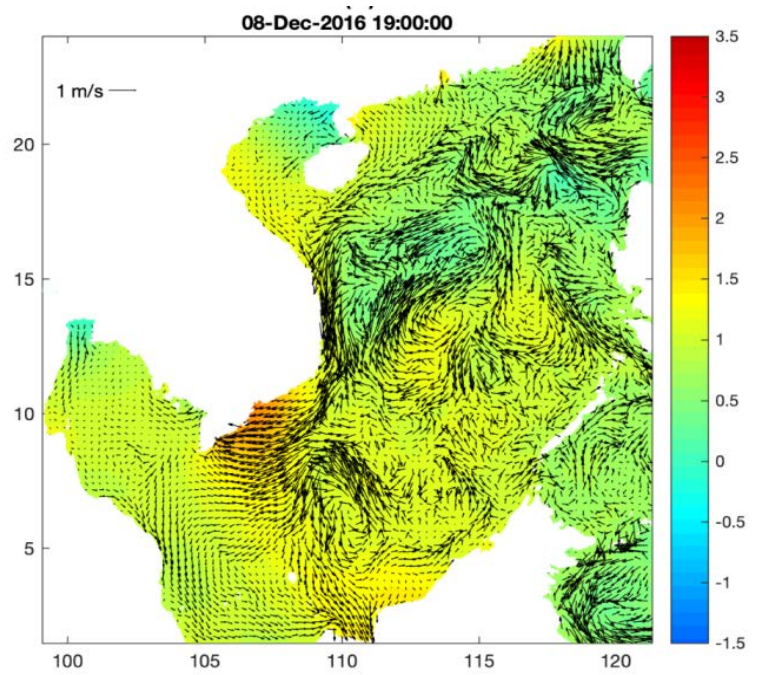

(a)

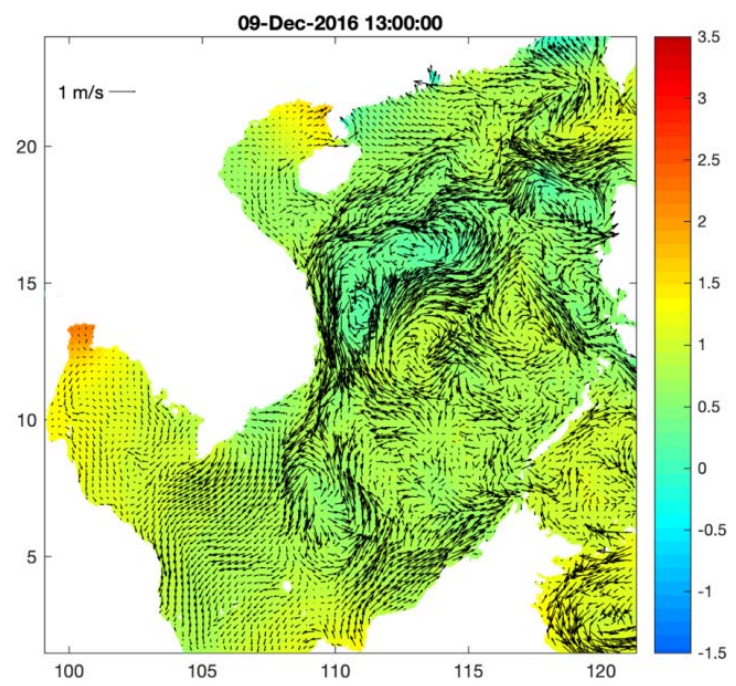

(b)

Hình 7. Trường mực nuớc và dòng chảy tại tầng mặt ngày 8/12/2016 (a) và 9/12/2016 (b)

\section{Kết luận}

Trên đây là một số kết quả ban đầu về nghiên cứu hiện tượng nước dâng do hiệu ứng bơm Ekman tại khu vực bằng mô hình ROMS 3D.Trong đó, các trường khí tượng được thu thập từ cơ sở dữ liệu tái phân tích của CFSR. Kết quả cho thấy có sự tương đồng về xu thế giữa nước dâng tinh toán và quan trắc, nhưng về biên độ còn thiên thấp so với thực tế. Trường gió Đông Bắc với vận tốc lớn, thời gian thổi lâu tạo nên dòng chảy hướng Bắc-Nam dọc ven bờ miền Trung gây hiệu ứng bơm Ekman đẩy mực nước dâng cao.

Để có thể mô phỏng đầy đủ định lượng hiện tượng nước dâng dị thường tại khu vực, cần thiết phải xét tới các hiệu ứng khác như tác động của ứng suất sóng. Ngoài ra, đối với nước dâng cao cục bộ tại vùng ven bờ, cần thiết phải xây dựng lưới tính của cả mô hình khí tượng và hải dương với độ phân giải cao hơn, đây cũng là nội dung nghiên cứu được thực hiện trong thời gian tới. Kết quả của nghiên cứu góp phần làm sáng tỏ nguyên nhân gây nước dâng dị thường tại khu vực.

Lời cảm ơn: Nghiên cứu này được tài trọ̣ bởi Quỹ Phát triển khoa học và công nghẹ Quốc gia (NAFOSTED) trong đề tài mã số 105.06-2017.07). Tác giả xin chân thành cảm ơn.

\section{Tài liệu tham khảo}

1. Trần Hồng Thái, Trần Quang Tiến, Nguyễn Bá Thủy, Dương Quốc Hùng (2017). Hiện tương mực nước biển dâng dị thường tại Tuy Hòa - Phú Yên. Tạp chí khí tượng thủy văn, số 676 trang $1-9$.

2. Nguyễn Bá Thủy, Trần Quang Tiến (2018). Bước đầu nghiên cứu mối liên hệ giữa mực nước biển dâng dị thuoòng tại Tuy Hòa - Phú Yên với hình thế thời tiết. Tạp chí khí tượng thủy văn. Số 687 , trang 15-22.

3. Bertin, X.; Li, K.; Roland, A., and Bidlot, J.R., (2015). The contribution of short waves in storm surges: two recent examples in the central part of the bay of Biscay. Continental Shelf Research 96, 1-15.

4. Centurioni, L. R., Niiler P. N., and Lee D.-K. (2009). Near-surface circulation in the South China Sea during the winter monsoon. Geophysical Research Letters, Vol. 36, L06605, 


\title{
BÀI BÁO KHOA HỌC
}

doi:10.1029/2008GL037076, 2009.

5. Forbes, C.; Rhome, J.; Mattocks, C.; Taylor, A. Predicting the Storm Surge Threat of Hurricane Sandy with the National Weather Service SLOSH Model (2014). Journal of Marine Science and Engineering, 2, 437-476. doi: 10.3390/jmse2020437.

6. Kim, S.Y.; Matsumi, Y.; Yasuda, T., and Mase, H., (2014). Storm surges along the Tottori coasts following a typhoon, Ocean Engineering, 91, 133-145.

7. Shaw, P.T., Chaao, S., Fu, L. (1998). Sea surface height variations in the South China Sea from satellite altimetry. Oceanologica Acta - Vol. 22 - No. 1.

8. https://hycom.org/data/glba0pt08/expt-91pt2.

9. https://www.myroms.org/wiki/Tidal_Forcing.

10. https://climatedataguide.ucar.edu/climate-data/climate-forecast-system-reanalysis-cfsr.

11. www.myroms.org.

\section{INITIAL STEP STUDY THE EKMAN PUMPING INDUCED ABNORMAL SURGE ON THE CENTRAL COAST OF VIETNAM}

\author{
Nguyen Ba Thuy ${ }^{1}$, Nguyen Kim Cuong ${ }^{2}$ \\ ${ }^{1}$ National Hydrometeorolocical Forecasting Center \\ ${ }^{2}$ VNU University of Science
}

\begin{abstract}
In this study, the abnormal surge during the spring tide phases at Tuy Hoa-Phu Yen in December 2016 was simulated by ROMS 3D model in order to investigate the surge induced by Ekman Pumping. The meteorology fields was obtaind from CFSR re-analysis database. The results indicate that the model simulated well the tendency of surge althought it underestimated. Strong and prolonged Northeast wind causes the longshore currents to create Ekman pump effect to push up the water level in the area.
\end{abstract}

Keywords: Abnormal surge, spring tide, Ekman pumping. 